\title{
Bioavailability of Nutrients for Improved Methane gas Production by Addition of Chelating Ligands
}

\author{
Nwokem N. C. ${ }^{1, *}$, Gimba C.E. ${ }^{1}$, Ndukwe G.I ${ }^{1}$. And Ella E.E. ${ }^{2}$ \\ ${ }^{1}$ Department of Chemistry, Ahmadu Bello University, Samaru-Zaria, Kaduna State, Nigeria. \\ ${ }^{2}$ Department of Microbiology, Ahmadu Bello University, Samaru-Zaria, Kaduna State, Nigeria. \\ *Corresponding author: nsidibe19@gmail.com
}

\begin{abstract}
Our irreplaceable fossil fuels are fast diminishing. Therefore, an important precautionary measure will be to develop renewable energy sources. Biogas is renewable and an environmentally friendly alternative energy. This research work focused on addition of chelating ligands in order to improve methane gas yield, and decrease concentration of Volatile Fatty Acid produced within digester systems. The experimental analysis carried out involved the use of Flame Atomic Absorption Spectrophotometer, Biogas5000 analyser and other classical analytical tools. The concentration of trace metals presents namely Iron, Cobalt, and Nickel ranged from 0.001-0.050 mg/L. On addition of chelating ligands, Ethylene diamine- $N, N$-diacetic acid, Nitrilotri-acetic acid and Diethylenetriamine-pentaacetic acid, an increase in the Methane yield was recorded which ranged from 2-15\%. The Volatile Fatty Acid concentration was generally low with values for Ethylene diamine- $N, N$ diacetic acid, Nitrilotri-acetic acid and Diethylenetriamine-pentaacetic acid given as $476.05 \mathrm{mg} / \mathrm{L}, 671.96$ $\mathrm{mg} / \mathrm{L}$, and $737.63 \mathrm{mg} / \mathrm{L}$ respectively; with $\mathrm{pH}$ ranging from 6-7.5. The improvement in methane gas yield was due to the increased bioavailability of essential nutrients on addition of chelating ligands which invariably promoted the growth and stability of the methane producing bacteria thereby, improving methane production. The Volatile Fatty Acid values which were generally lower than $2000 \mathrm{mg} / \mathrm{L}$ are implicated in the high methane gas yield observed.
\end{abstract}

Keywords: Methane, Nitrilotri-acetic acid, Ethylene diamine- $N, N$-diacetic acid, Diethylenetriamine-pentaacetic acid, Biogas5000.

\section{Introduction}

Reliance on fossil fuels importation from foreign countries creates a status of dependency and insecurity for most countries around the world. Also, the sources of fossil fuels are fast diminishing causing a lot of apprehension in our world today. The world's dependence on the declining reserves of fossils fuels poses not only environmental problems but also geopolitical ones (Angela et al., 2012). Therefore, an important precautionary measure will be to develop alternative renewable energy sources; taking into consideration the increased level of energy consumption and mitigation of environmental pollution.

The emergence of biogas is currently engaging public interest as supplement to oil base to serve as transportation or automobile fuels and also sources of heat and electricity generation supplies. Biogas is renewable and an environmentally friendly alternative energy as compared to non-renewable fossil fuels because it burns with minimal release of Carbon (IV) oxide and water (Teodorita et al., 2008). It is obtained through the process of anaerobic degradation of waste (Callander and Barford, 1983) and consists of methane $\left(\mathrm{CH}_{4}\right)$, Carbon (IV) oxide $\left(\mathrm{CO}_{2}\right)$ and Hydrogen sulphide $\left(\mathrm{H}_{2} \mathrm{~S}\right)$. This process of anaerobic degradation is carried out by a variety of micro-organisms, which are greatly influenced by some critical parameters; these conditions include: temperature, $\mathrm{pH}$-value and available nutrients. Thus, it becomes imperative that the optimum conditions of operation for the anaerobic microorganisms be provided which will in turn improve the percentage yield of $\mathrm{CH}_{4}$ which is the main constituent of biogas of fuel value.

The use of additives is fast becoming the focus of research efforts into the optimization of $\mathrm{CH}_{4}$ gas produced from smaller digesters. Uemura (2010), observed that the addition of minerals [Nickel (Ni), Cobalt (Co) and Iron $(\mathrm{Fe})]$ in batch mesophilic digesters, improved the digesters performance and $\mathrm{CH}_{4}$ gas yield. More so, the additives helped to maintain favourable conditions such as $\mathrm{pH}$ and promotion of methanogenesis within the digester for rapid biogas production (Hanaki et al., 1994). The focus of this research is to use chelating ligands[Ethylene diamine-N,N-diacetic acid (EDDA), Nitrilotri-acetic acid (NTA) and Diethylenetriaminepentaacetic acid (DTPA)] to improve $\mathrm{CH}_{4}$ gas potential by enhancing the microorganism population through the creation of nutrient rich environment favourable for the growth of methanogenesis from Cow manure substrate $(\mathrm{CM})$. 


\section{1}

\section{Materials And Methods}

The EDDA, NTA and DTPA chelating ligands used were purchased from Sigma Aldrich; while the Cow manure waste sample (substrate) was obtained from the Anguwan-Yusi, Hanwa N/Extension, Zaria, Kaduna. All reagents used were of analytical grade.

\subsection{Preparation of $\mathbf{1 0 0 0} \boldsymbol{\mu M}$ Chelating Ligand Stock Solutions}

Appropriate weights of each of the salts were weighed out into a $1000 \mathrm{~cm}^{3}$ volumetric flask containing $500 \mathrm{~cm}^{3}$ of deionized water. The mixtures were each stirred continuously with a glass rod till a solution was obtained which was then diluted to the mark with deionized water.

\subsection{Preparation of Chelating Ligand Standard Solutions}

Standard solution of $10 \mu \mathrm{M}, 50 \mu \mathrm{M}$ and $100 \mu \mathrm{M}$ for the chelating ligand were made from the stock solution and stored in sterilized amber-coloured bottles.

\subsection{Waste Sample Preparation}

The waste sample was air-dried for 72 hours and ground to smaller particles sizes of about $30.0 \mathrm{~nm}$ with a mortar and pestle. The sample was then properly labelled and stored in an air-tight plastic container until when needed.

\subsection{Trace Metal Determination}

\section{Laboratory Analysis}

The concentrations of $\mathrm{Fe}, \mathrm{Co}$ and $\mathrm{Ni}$ in the $\mathrm{CM}$ sample were determined by flame atomic absorption spectrophotometer (AAS) version AA240FS.

\subsection{Biogas Sample Analysis}

Figure 1 shows the experimental setup for the biogas production. The systems were operated at mesophilic temperature. Two litres Pyrex digester bottles were used. Two hundred grammes of the dry waste samples were each loaded into the digesters and 1.5 litres of deionized water was added. The digesters were sealed with a rubber bung having two bore holes to exclude air from getting into the digesters. One hole was used for temperature determination, while the other was connected to delivery tubing which was used to collect and measure the volume of biogas produced under water through the downward displacement of water method. The digesters were subjected to periodic agitation to ensure thorough mixing of the contents while maintaining intimate contact between the micro-organisms and the substrate to enhance the complete digestion of the substrate. The composition of the biogas produced was equally monitored using a biogas analyzer (Biogas 5000, UK) on a daily basis.

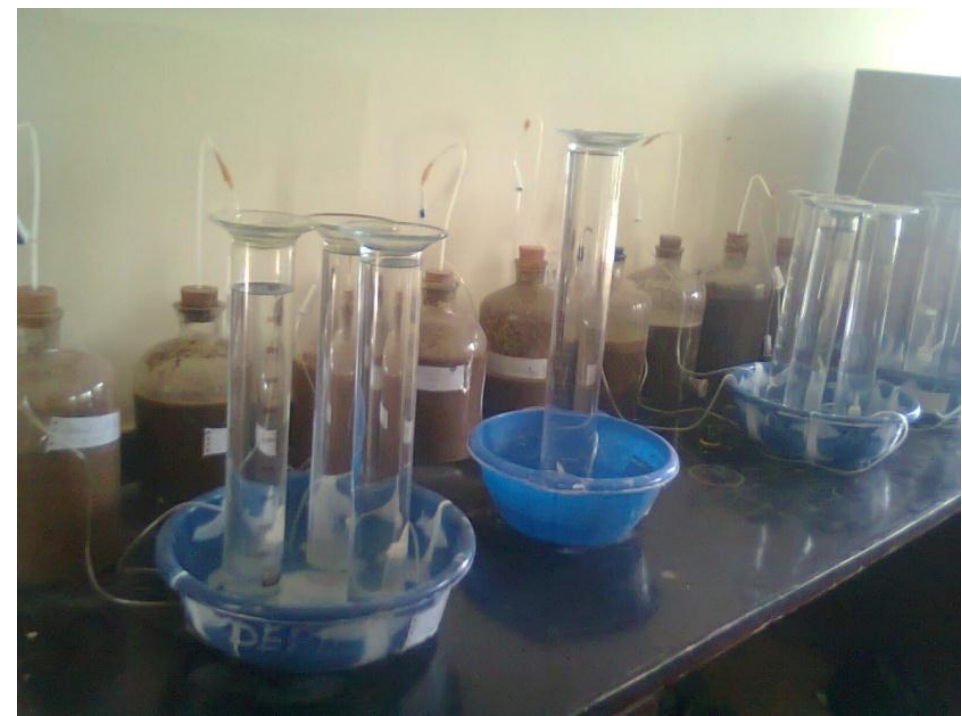

Figure 1:

Biogas production Setup 


\subsection{VFA Analysis}

Before analysis, the samples from each digester were filtered through a $0.45 \mu \mathrm{m}$ membrane filter. The filtered $20 \mathrm{~cm}^{3}$ samples were transferred into a $100 \mathrm{~cm}^{3}$ Pyrex beaker. The initial pHs of the filtrates was determined using the $\mathrm{pH}$ meter (Jenway 1000, UK). The samples were titrated slowly with $0.05 \mathrm{M}$ sulphuric acid until $\mathrm{pH}$ of 5.0 was reached. The added volume of titrant was recorded. More acid was slowly added until $\mathrm{pH}$ of 4.3 was reached. The total volume of the added titrant was again recorded. The latter step was repeated until pH of 4.0 was reached; the volume of the added titrant was again recorded. The concentration of VFA was then calculated using the formula:

$$
\mathrm{Sa}=\frac{131340 . \mathrm{M} \cdot \mathrm{VA}_{5-4, \text { meas }}}{\mathrm{Vs}} \quad-\quad 3.08 . \mathrm{Alk}_{\text {meas }}-25
$$

Where $\quad \mathrm{Sa}=$ concentration of VFA

$$
\mathrm{M}=\text { Molarity }
$$

$\mathrm{VA}_{5-4, \text { meas }}=$ volume of acid $\left(\mathrm{cm}^{3}\right)$ required to titrate a sample from $\mathrm{pH} 5.0$ to $\mathrm{pH} 4.0$.

$\mathrm{Vs}=$ volume of sample $\left(\mathrm{cm}^{3}\right)$

$$
\begin{aligned}
& \mathrm{Alk}_{\text {meas }}=\text { measured alkalinity } \\
& {\left[\mathrm{Alk}_{\text {meas }}=\frac{\mathrm{VA}}{\mathrm{Vs}} \cdot \frac{\mathrm{M} \text { meas }}{. \mathrm{M} .1000}\right]}
\end{aligned}
$$

\subsection{Analysis of Data}

Data collected at the end of the study were analysed using statistical package for social sciences (SPSS) version 15.0 (SPSS Inc. Chicago, IL, USA).

\subsection{Effect of Trace Metals on $\mathrm{CH}_{4}$ gas Yield}

\section{Results and Discussion}

One of the factors which determine the performance of an anaerobic digester system is the concentration of the trace metals $\mathrm{Fe}, \mathrm{Co}$, and $\mathrm{Ni}$; which are particularly important to the rapid growth of bacteria (Mosey et al., 1997). The amount of trace metals present in the digester is presented in Figure 2. High concentrations of Cobalt and Nickel usually have an inhibitory effect on the anaerobic digester system. Thus, the presence of these metal ions within the minimum acceptable range is necessary to enhance $\mathrm{CH}_{4}$ gas production. Results from Figure 2 show the presence of these metal ions at the acceptable range (0.001-0.050 $\mathrm{mg} / \mathrm{L}$ ) for samples taken out of the CM digester system. Since these metals are present at sufficient and balanced nutrient levels, thus, explains the reason for the high $\mathrm{CH}_{4}$ gas yield obtained from the system.

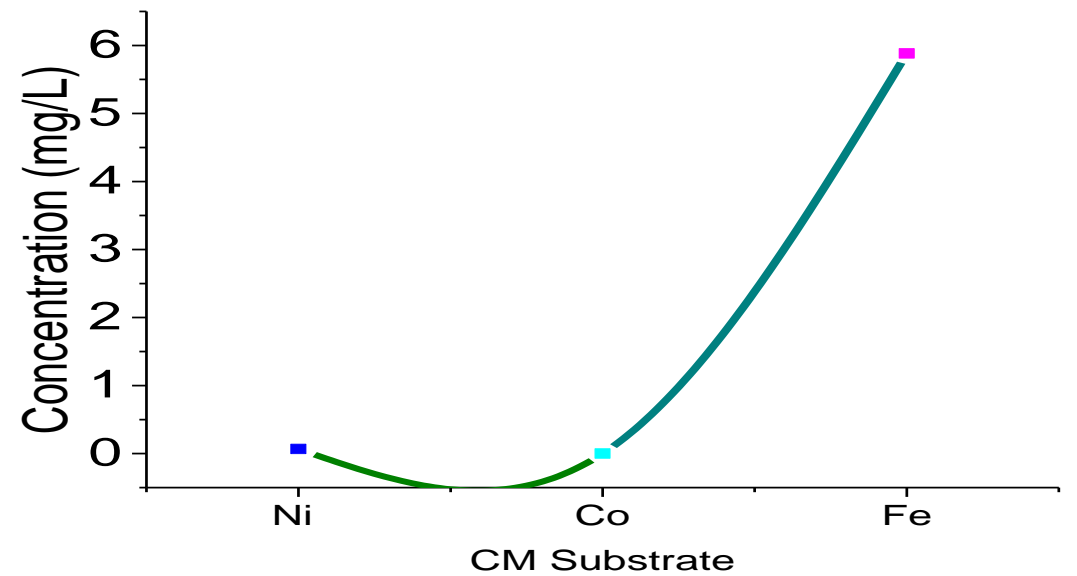

Figure 2: $\quad$ Results Showing the Concentration of Trace Metals in CMSubstrate

\subsection{Effect of Addition of Chelating Ligands}

In a bid to improve the performance of the $\mathrm{CM}$ digester, the following ligands were added prior to the commencement of the anaerobic digestion process: EDDA, NTA, and DTPA. Figure 3 shows that on addition of these chelating ligands, an increase which ranged from 2-15\% in the $\mathrm{CH}_{4}$ gas produced was recorded.

The NTA chelating ligand performed best with a $15 \%$ improvement in the $\mathrm{CH}_{4}$ gas yield $\left(72.2 \% \mathrm{CH}_{4}\right.$ produced) over the control which recorded a $\mathrm{CH}_{4}$ gas yield of $64.4 \%$. EDDA chelating ligand showed $12 \%$ increase in $\mathrm{CH}_{4}$ 
production (70.5\% $\mathrm{CH}_{4}$ gas yield) and then DTPA showed $2 \%$ improvement in $\mathrm{CH}_{4}$ production $\left(65.6 \% \mathrm{CH}_{4}\right.$ gas yield) compared to the control.

A partial list of chelating ligands and there log stability constants is given in Table 1 . The uptake of these metals within the CM substrate depends on the metal speciation and bioavailability. The speciation is controlled by metal concentrations, digester operational conditions as well as chemical processes such as complexation (Mosey et al., 1971; Pinheiro and van Leewen, 2001). It is also assumed that these metals are only available for microbial uptake when they are present as free metal ions and as metal complexes in the soluble form (Saito et al., 2002; Worms et al., 2006). Since most of these metals are present as metal sulphides within the digester systems (Rinzema and Lettinga, 1988); therefore the presence of organic and inorganic chelates will affect the metal bioavailability by the formation of metal chelates with high stability constants. Note that the larger the stability constant, the higher the proportion of the chelates that exists in solution and thus, the greater its availability to the methanogens (Marvin, 1989). Therefore, it is believed that stimulation of the anaerobic digestion process results from the degree of binding of $\mathrm{Fe} \mathrm{Co}$ and $\mathrm{Ni}$ to chelating ligands in the various substrates. This leads to an increase in the solubility of these essential inorganic nutrients which in turn promotes the growth and stability of the methanogenic population and thereby improving methane production.

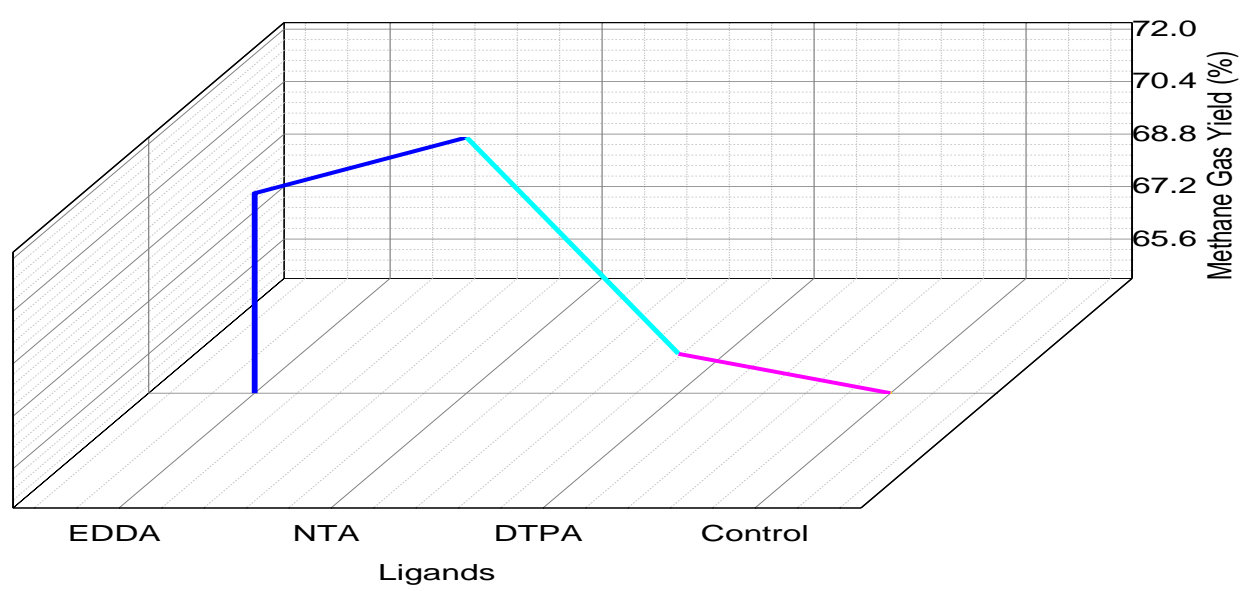

Figure 3: $\quad$ Results Showing the Effect of Chelating Ligands on $\mathrm{CH}_{4}$ gas Yield

In addition, chelating ligands which form lipophilic complexes may permeate the plasma membrane of an organism (methanogen) and assist in the uptake of metal ions. This explains why the addition of the chelating ligand DTPA to the digester systems (which form stable complexes with $\mathrm{Fe}, \mathrm{Ni}$ and $\mathrm{Co}$ ) does not bring about a significant improvement in $\mathrm{CH}_{4}$-production. DTPA is poorly absorbed into cells of methanogens which limits their capacity to chelate-out metals from inside the cells of the methanogens (Klaaseen, 2006). This is likely responsible for the not-so significant $\mathrm{CH}_{4}$-production observed in some digester systems into which they were added.

Though NTA and EDDA form stable chelates with Fe, Co and Ni as is the case with DTPA, their complexes are lipophilic (Haitwig et al., 1993). As a result, NTA and EDDA are able to permeate the membranes of the methanogens allowing them to reach the sites of metal storage and thus form stable complexes with these metal ions thereby leading to the significant improvement in $\mathrm{CH}_{4}$-production observed within those digesters.

Table 1: Logarithm Stability Constants of Chelating Ligands Employed in This Study

\begin{tabular}{|c|c|c|c|}
\hline Chelating Ligand & $\mathbf{F e}^{3+}$ & $\mathbf{C o}^{2+}$ & $\mathbf{N i}^{2+}$ \\
\hline EDDA & 8.63 & 11.25 & 13.6 \\
\hline NTA & 15.87 & 10.38 & 11.54 \\
\hline DTPA & 28.60 & 18.40 & 20.32 \\
\hline
\end{tabular}

\subsection{Effect of Addition of Chelating Ligands on VFA}

The varying performance of the digester systems seen in Figure 3 can be attributed to the VFA concentrations of the systems. Various studies have tried to draw a correlation between the concentration of VFA and the health of the anaerobic digestion system (Hill and Holmberg, 1988). Therefore, a well working biogas digester is characterized by low levels of fermentation intermediates and VFA concentration of less than $2000 \mathrm{mg} / \mathrm{L}$ (Hill and Holmberg, 1988). 


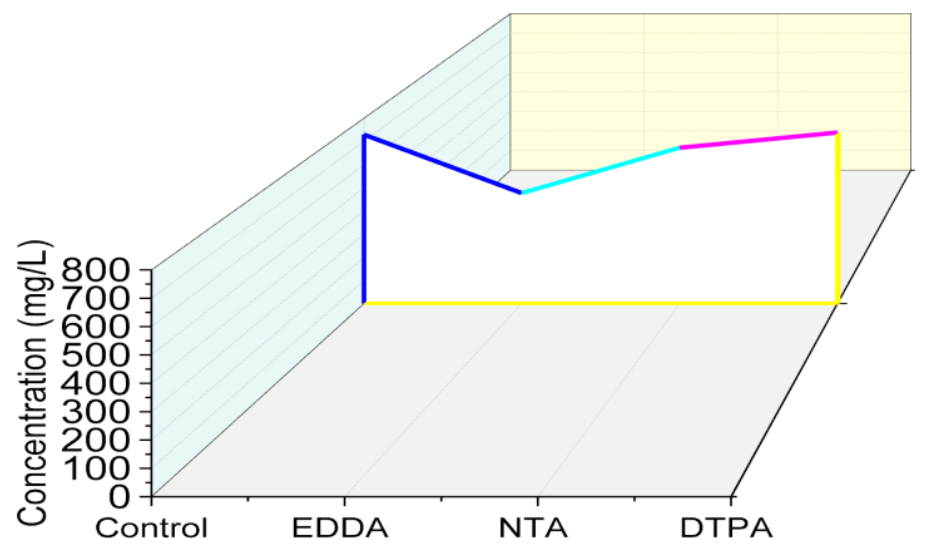

Ligands

Figure 4: $\quad$ Result Showing the Effect of Addition of Chelating Ligand on VFA Concentration

The final VFA concentration for EDDA containing digester systems was recorded as $476.05 \mathrm{mg} / \mathrm{L}$; NTA had a final VFA concentration value of $671.96 \mathrm{mg} / \mathrm{L}$, while DTPA recorded a final VFA value of 737.63 $\mathrm{mg} / \mathrm{L}$ against the control which had a concentration of $644.48 \mathrm{mg} / \mathrm{L}$. This low VFA concentration levels in EDDA, NTA and DTPA is implicated in the high $\mathrm{CH}_{4}$ gas yield observed with these digester systems. In general, the VFA concentrations were significantly lower than $2000 \mathrm{mg} / \mathrm{L}$ with $\mathrm{pH}$ range between 6-7.5 (see Table 2); indicating that all the anaerobic digester systems performed appreciably above average.

Table 2: Result Showing the Effect of Addition of Chelating Ligand on pH

\section{Substrate}

\begin{tabular}{|c|c|c|c|}
\hline WEEK & EDDA & NTA & DTPA \\
\hline 1 & 6.04 & 6.00 & 6.05 \\
\hline 2 & 7.37 & 7.38 & 7.54 \\
\hline 3 & 7.50 & 7.37 & 7.49 \\
\hline
\end{tabular}

\subsection{Conclusion}

In conclusion, the results show that the addition of EDDA, NTA, and DTPA to digester systems helped improve the $\mathrm{CH}_{4}$ gas produced significantly by $2-15 \%$. Thus, the use of chelating ligands has been shown to be a promising and sure way of improving the percentage of $\mathrm{CH}_{4}$ gas produced from solid waste digester systems.

\section{Reference}

[1]. CALLANDER, I.J. and Barford, J.P. (1983). Recent Advances in Anaerobic Digestion Technology. Process Biochemistry, 18, 24 30.

[2]. $\quad$ ANGELA, M.R., Kevin, M.R., Tracy, L.H. (2012). Predicting Litter and Live Herb Fuel Consumption during prescribed Fires in native and old-field Upland Pine Communities of the Southeastern United States. Canadian Journal of Forest Research, 42(8):16111622.

[3]. HANAKI, K., Hirunmasuwan, S., Matsuo, T. (1994). Protection of Methanogenic Bacteria From Low ph and Toxic Materials by Immobilization Using Polyvinyl Alcohol. Water Research. 28: 877-885.

[4]. HILL D.H. and Holmberg R. (1988). Long Chain Volatile Fatty Acid Relationships in Anaerobic Digester Failure. Biological Wastes, 23, 195-214

[5]. KLAASSEN A. J. (2006). Nonparametric and Semiparametric Models 10.1111/j.15410420.2006.00589

[6]. MARVIN K. (1989). Release of Outer Membrane Fragment, Journal of Bacteriology, pp. 5262 - 5267.

[7]. MOSEY F. E., Swanwick J. D. and Hughes D. A. (1971). Factors Affecting the Availability of Heavy Metals to inhibit Anaerobic Digestion. Journal of Institute of Water Pollution Control 6 p 34-40.

[8]. MOSEY, F.E. and Fernandes, X.A. (1989). Patterns of Hydrogen in Biogas from The Anaerobic-Digestion Of Milk-Sugars. Water Science and Technology. 21: 187-196.

[9]. PINHEIRO J.P and van Leeuwen H.P, "Speciation dynamics and bioavailability of metals. Exploration of the case of two uptake routes", Pure and Applied Chemistry, 73(1), 2001, pp. 39-44

[10]. RINZEMA, A., Lettinga, G. ( 1988). The Effect of Sulphide on the Anaerobic Degradation of propionate. Environmental Technology Letters 9, 83-88

[11]. SAITO, M. A., MoffetT, J.W., Chisholm, S.W. and Waterbury, J.B. (2002). Cobalt limitation and uptake in Prochlorococcus. Limnology and Oceanography. 47: 1629-1636.

[12]. TEODORITA, A.S., Dominik, R.., Heinz, P., Michael, K., Tobias, F., Silke, V. and Rainer J. (2008). Biogas Handbook. University of Southern Denmark, Esbjerg, Niels Bohrs, Denmark, pp. $10-50$.

[13]. UEMURA, S.H. ( 2010). Mineral Requirements for Mesophitic and thermophitic Anaerobic Digestion of Organic waste. International Journal of Enviromental Research, 4(1): 33-4.

[14]. WORM, B., E. B. Barbier, N. Beaumont, J.E. Duffy, C. Folke, B.S. Halpern, J.B.C. Jackson, H.K. Lotze, F. Micheli, S.R. Palumbi, E. Sala, K.A. Selkoe, J.J. Stachowicz and R. Watson. (2006). Impacts of Biodiversity Loss on Ocean Ecosystem Services. Science 314:787-790. 